\title{
Time Series Modeling of Dynamic Responses of Commodity Prices to Monetary Policy Shocks in Ghana
}

\author{
Ernest Yeboah Boateng1 ${ }^{*}$, Paul K. Yeboah², Isaac Christopher Otoo ${ }^{3}$, Joseph Otoo ${ }^{4,5}$ \\ ${ }^{1}$ Department of Basic Sciences, School of Basic and Biomedical Sciences, University of Health and Allied Sciences, Ho, Ghana \\ ${ }^{2}$ Finance Department, Catholic University College of Ghana, Fiapre, Ghana \\ ${ }^{3}$ Department of Finance, School of Business, College of Humanities and Social Sciences, University of Cape Coast, Cape Coast, \\ Ghana \\ ${ }^{4}$ Department of Statistics and Actuarial Science, University of Ghana, Accra, Ghana \\ ${ }^{5}$ Centre for Research, Data Science and IT Solutions, Ho, Ghana \\ Email: *eyboateng@uhas.edu.gh, paul.yeboah@cug.edu.gh, isaac.otoo@ucc.edu.gh, jotoo011@st.ug.edu.gh
}

How to cite this paper: Boateng, E. Y., Yeboah, P. K., Otoo, I. C., \& Otoo, J. (2020). Time Series Modeling of Dynamic Responses of Commodity Prices to Monetary Policy Shocks in Ghana. Journal of Financial Risk Management, 9, 377-389. https://doi.org/10.4236/jfrm.2020.94020

Received: August 22, 2020

Accepted: November 3, 2020

Published: November 6, 2020

Copyright (c) 2020 by author(s) and Scientific Research Publishing Inc. This work is licensed under the Creative Commons Attribution International License (CC BY 4.0).

http://creativecommons.org/licenses/by/4.0/

\begin{abstract}
The Vector Error Correction (VEC) model was used to assess the impact of monetary policy rate on commodity prices in Ghana. Monthly data on monetary policy rate, commodity prices of cocoa, gold and crude oil from January 2005 to December 2017 obtained from the Bank of Ghana was used for the study. The estimated VEC model aided in establishing long and short run relationships between monetary policy rates and the major commodity prices in Ghana. The study revealed that in the long run, monetary policy rates are negatively correlated to crude oil prices, positively correlated to both cocoa prices and gold prices but to a little extent. It was also evident from the study that in the short run, the first lag of monetary policy rate is negatively related to itself and the second lag of monetary policy rate is positively related to itself. Additionally, the first and second lagged periods of cocoa price have positive influence on monetary policy rate in the short run, but the first and second lagged periods of gold price have negative influence on monetary policy rates in the short run. The Granger causality test also reveals that the movement of cocoa prices in Ghana can be explained to cause the movement of monetary policy rates and gold prices in short run. A positive shock in monetary policy rate will have a positive and persistent effect on itself. Likewise, positive shock in monetary policy rate will have a positive and persistent effect on cocoa prices. The response generated from a positive shock on monetary policy rate has a persistent and decreasing effect on both crude oil and gold prices.
\end{abstract}




\section{Keywords}

Crude Oil Price, Monetary Policy Rate, Vector Autoregressive Model, Co-Integration, Granger Causality Test

\section{Introduction}

The development of commodity prices has been one of the major foundations of concern for policy makers during the past decades. From unindustrialized countries to developed markets around the world, commodity prices have a great influence on the undercurrents of economic activity. Their intercontinental trade represents one-quarter of the world's merchandise exchange (Thomasz, Massot, \& Rondinone, 2016).

A hefty share of unindustrialized world's GDP comes from commodity related activities. Hence, both long-term trends and short-term fluctuations in commodity prices are key determinants of exchange rates, prices, national income and the balance of payments (Blanchard \& Gali, 2007). In nations with low monetary policy standing where the share of commodities in the consumption basket is great, food and fuel price shocks might also raise expectations of larger inflation in the future (Bleaney \& Greenaway, 1993).

Unlike factory-made goods, primary products have flexible prices which respond very quickly to macroeconomic fundamentals and other intercontinental finance concepts. Commodity markets are characterized by spreading shocks between markets; they connect commodity importing countries, usually developed economies, with emerging exporter countries (Tang \& Xiong, 2012).

Anzuini, Lombardi, \& Pagano (2012) and Frankel (2008) revealed that monetary policy and interest rate were main driving forces of commodity price and monetary policy affects commodity price through supply and demand forces. From demand side, low interest rate (expansionary policy) reduces opportunity cost of holding money, increases demand for commodities which in turn raises price level of economy. From supply side, low interest rate induces firms to not extract their inventories which in turn diminish supply level and lift up prices of economy (Anzuini \& Fornari, 2012). Similarly, Jeffrey A. Frankel (2005), keeping in view Dornbusch overshooting theory, explored that high interest rates lead to diminish commodity prices through reducing demand for carrying commodity inventories thereby encouraging speculators to shift out of commodity contracts into treasury bills.

Jeffrey A. Frankel (1986) derived a theoretical no-arbitrage link between oil prices and monetary policy. Again, Jeffrey A. Frankel \& Rose (2010) assessed empirically the link commodity prices and monetary policy by using interest rates and concluded that interest rates may not fully represent the impact of a monetary policy shock. Empirical results indicate that tight monetary policy shocks have positive effects on commodity prices, which respond quickly to pol- 
icy shocks and cost push supply shocks. Moreover, tight monetary policy has negative effects on real activity of economy that is industrial productivity. Impulse response also demonstrates similar results and commodity prices response positively to positive interest rate shocks (Cabrales, Granados Castro, \& Ojeda Joya, 2014).

Having information about the behaviour of commodity prices is crucial for economic authorities to be able to design and implement economic policies since it could affect prices as well as national income, the exchange rate, the current account and the fiscal balance. The behaviour of commodity prices also determines portfolio, investment and consumption decisions (Henderson, Pearson, \& Wang, 2014).

This paper presents a scholarly analysis of the impact of monetary policy shocks on commodity prices in Ghana, employing the Vector Error Correction (VEC) model. Specifically, the paper seeks to identify a monetary policy shock in a VEC model and assess its impact on commodity prices, the projection of each of the commodity prices on this shock and also determine an empirical evidence of the significance of these impacts of monetary policy on commodity prices.

\section{Materials and Methods}

\subsection{Data}

The data for the study comprises monthly monetary policy rate (MPR), monthly commodity prices on cocoa (COC), gold (GLD) and crude oil (CRU) from January, 2005 to December, 2017 was obtained from the Bank of Ghana. It is worth noting that these commodities are the major commodities of Ghana. Additionally, empirical evidence (Lütkepohl, Krätzig, \& Phillips, 2004) indicates that increasing the number of variables (commodities) and equations does not generally lead to a better model because doing so makes it more difficult to capture the dynamic, inter-temporal relations between variables of interest. In essence, increasing the number of commodities in this study will lead to insufficient representation of the dynamic interactions in the system of variables.

\subsection{Vector Auto-Regression (VAR) and Vector Error Correction (VEC) Models}

Sims (1980) defined a VAR as an ad hoc dynamic multivariate model that treats simultaneous set of variables equally and in a manner that endogenous variables are regressed on its own lags and the lags of all other variables in a finite-order system. This approach enables the examination of a dynamic response of a system to the shocks without having to depend on restrictions inherent in structural models.

A VAR model as captured in Bernanke \& Blinder (1992), Christiano, Eichenbaum, \& Evans (1998) and Ford, Agung, Ahmed, \& Santoso (2003) can be expressed as:

$$
B y_{t}=C(L) y_{t}+D(L) x_{t}+\varepsilon_{t}
$$


where $y_{t}$ is a $m \times 1$ vector of endogenous variables, $x_{t}$ is an " $n$ " vector of exogenous variables, $B, C$ and $D$ are matrices of the estimated coefficients, $L$ is a lag operator and $i$ is the number of lags or the order of the VAR. The error term $\varepsilon_{t}$ is a vector of innovation that are i.i.d.

The reduced form of Equation (1) can be expressed as an MA representation:

$$
y_{t}=\frac{1}{I-A(L)} v_{t}=K(L) v_{t}
$$

where $A(L)=B^{-1} C(L)=A_{1} L+\cdots+A_{i} L^{i}, v_{t}=B^{-1} \varepsilon_{t}$

The structural form or the estimated VAR can be obtained from equation (2). This aids in the estimation of impulse response functions and variance decomposition functions.

However, if all variables in Equation (1) are integrated with order 1 that is $\mathrm{I}(1)$, and if there exist co-integration relationships among them, then the resulting model is a Vector Error Correction Model (VECM) which can be specified as:

$$
\Delta y_{t}=\alpha \beta^{\prime} y_{t-1}-\sum_{j=1}^{\infty} A_{j} \Delta y_{t-j}+\varepsilon_{t}
$$

In this study, all the variables were $\mathrm{I}(1)$ with co-integration requiring the formulation of a VEC model specified as follows:

Long run relation

$$
\mathrm{ECM}=\beta_{0} \ln \mathrm{MPR}+\beta_{1} \mathrm{CRU}+\beta_{2} \ln \mathrm{COC}+\beta_{3} \ln \mathrm{GLD}+C
$$

Short run relation

$$
\begin{aligned}
\Delta \ln \mathrm{MPR}_{t}= & \alpha_{0} \mathrm{ECM}_{t}+\alpha_{1} \Delta \ln \mathrm{MPR}_{t-1}+\alpha_{2} \Delta \ln \mathrm{MPR}_{t-2}+\alpha_{3} \Delta \mathrm{CRU}_{t-1} \\
& +\alpha_{4} \Delta \mathrm{CRU}_{t-2}+\alpha_{5} \Delta \ln \mathrm{COC}_{t-1}+\alpha_{6} \Delta \ln \mathrm{COC}_{t-2} \\
& +\alpha_{7} \Delta \ln \mathrm{GLD}_{t-1}+\alpha_{8} \Delta \ln \mathrm{GLD}_{t-2}+K
\end{aligned}
$$

where ECM is the error correction term for both the long and the short run relationship, MPR, CRU, COC and GLD have their meanings as already defined.

\section{Results and Discussions}

The time series plots for crude oil, gold, cocoa and monetary policy rates are captured in Figure 1. The series plot with regards to monetary policy rates shows a decreasing trend from year 2005 through the year 2008. Between the years 2008 and 2010, there was increasing or upward trend of monetary policy rates. The series plot shows a downward or decreasing trend of monetary policy rates from the year 2010 through 2012. From the year 2012 through 2016, the series plot shows increasing trend of monetary policy rates.

In the context of gold and cocoa, the series plots show increasing trend of prices from the year 2005 through 2016. For crude oil, the series plot depicts increasing trend from the year 2005 through 2008; a decreasing trend from the month of January, 2008 through June, 2008; an upward trend from June, 2008 through January, 2014; and a decreasing trend of prices of crude oil from Janu- 
ary, 2014 through the year 2016.

In checking for the stationarity of the variables, the Augmented Dicker-Fuller unit root test and the Philips-Perron test were employed. It is evident from Table 1 and Table 2 that the variables attained stationarity after they were differenced once, that is, the p-values of original series are bigger than $5 \%$ and the p-values of 1 -st difference are smaller than $5 \%$, which indicates we can reject the null hypothesis and conclude that the data is stationary.

As can be seen from Table 3, the p-values of Trace Statistic and Max-Eigen Statistic are smaller than $5 \%$ for the null hypothesis of none of co-integration

\section{COMMODITY PRICES OF GHANA FROM 2005 TO 2017}
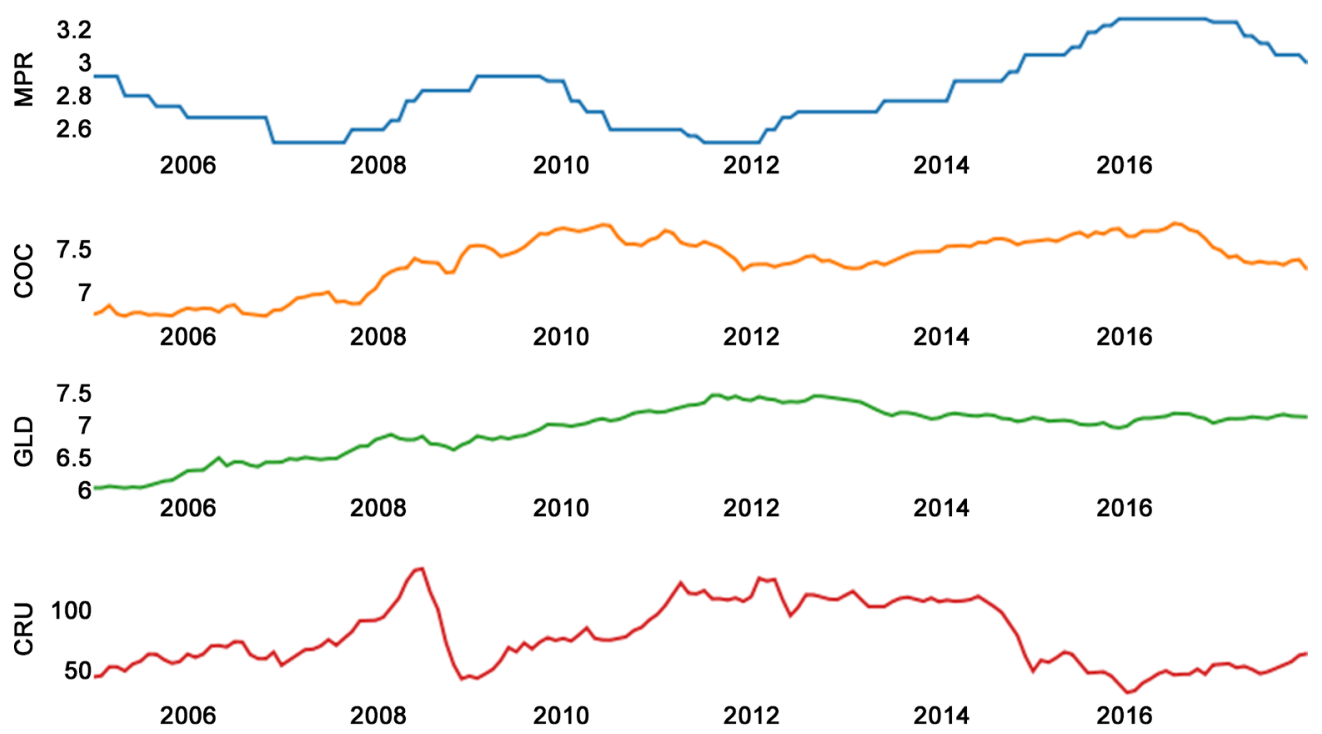

Figure 1. Monthly time series plot of crude oil, gold, cocoa and monetary policy rate of Ghana.

Table 1. ADF unit root test.

\begin{tabular}{ccccc}
\hline Variable & $\begin{array}{c}\text { Level } \\
\text { t-statistic }\end{array}$ & $\begin{array}{c}\text { Level } \\
\text { P-value }\end{array}$ & $\begin{array}{c}\text { Differenced } \\
\text { t-statistic }\end{array}$ & $\begin{array}{c}\text { Differenced } \\
\text { P-value }\end{array}$ \\
\hline MPR & -0.184310 & 0.6183 & -6.109479 & 0.0000 \\
CRUDE OIL & -0.640914 & 0.4382 & -7.991862 & 0.0000 \\
COCOA & -0.193012 & 0.6152 & -9.244762 & 0.0000 \\
GOLD & 0.846189 & 0.8923 & -10.33796 & 0.0000 \\
\hline
\end{tabular}

Table 2. PP unit root test.

\begin{tabular}{ccccc}
\hline Variable & $\begin{array}{c}\text { Level } \\
\text { t-statistic }\end{array}$ & $\begin{array}{c}\text { Level } \\
\text { P-value }\end{array}$ & $\begin{array}{c}\text { Differenced } \\
\text { t-statistic }\end{array}$ & $\begin{array}{c}\text { Differenced } \\
\text { P-value }\end{array}$ \\
\hline MPR & -0.138871 & 0.6343 & -13.13974 & 0.0000 \\
CRUDE OIL & -0.531852 & 0.4851 & -8.030367 & 0.0000 \\
COCOA & -0.062226 & 0.6605 & -9.034214 & 0.0000 \\
GOLD & 0.696265 & 0.8649 & -10.33796 & 0.0000 \\
\hline
\end{tabular}


Table 3. Co-integration test.

\begin{tabular}{cccc}
\hline $\begin{array}{c}\text { Hypothesized } \\
\text { No. of CE(s) }\end{array}$ & Eigenvalue & $\begin{array}{c}\text { P-value } \\
\text { (Trace) }\end{array}$ & $\begin{array}{c}\text { P-value } \\
\text { (Max-Eigen) }\end{array}$ \\
\hline None $^{*}$ & 0.206008 & 0.0096 & 0.0042 \\
At most 1 & 0.071512 & 0.4534 & 0.6122 \\
At most 2 & 0.037293 & 0.4438 & 0.6371 \\
At most 3 & 0.015500 & 0.1221 & 0.1221 \\
\hline
\end{tabular}

equations (CEs), which indicates we can reject it. And the P-values of Trace Statistic and Max-Eigen Statistic are bigger than 5\% for the null hypothesis of at most 1 of $\mathrm{CE}(\mathrm{s})$, which indicates we can accept it. Both Trace test and Max-eigenvalue test indicate 1 co-integrating eqn(s) at the $5 \%$ level.

The co-integration relationship as captured by Table 3 implies the existence of the long term equilibrium relationship of the variables and the short term disequilibrium of the generation of dynamic process. Following this result, VEC model was estimated to describe the short-term dynamic disequilibrium among MPR, CRU, COC and GLD. Selection of lags for the VEC model was based on the criterion of AIC and SC. Results from AIC and SC suggest the optimal lag length 2 for the VEC model. The results are as follows:

\section{Long run relationship}

$$
\begin{aligned}
\mathrm{ECM}= & \ln \mathrm{MPR}+0.221928 \mathrm{CRU}-0.000698 \ln \mathrm{COC} \\
& -0.008232 \ln \mathrm{GLD}-24.48935
\end{aligned}
$$

Equation (6) (Error Correction Model) captures the long run relationships between MPR and major commodity prices in Ghana. The model reveals that in the long run, monetary policy rates are negatively correlated to crude oil prices, when crude oil prices increases $1 \%$, the monetary policy rates fall by $0.22 \%$; monetary policy rates are positively correlated to cocoa prices but to a little extent, when cocoa prices increases $100 \%$, the monetary policy rates increase by $0.06 \%$; and monetary policy rates are positively correlated to gold prices but to a little extent, when gold prices increases $10 \%$, the monetary policy rates increase by $0.08 \%$.

\section{Short run relationship for MPR}

$$
\begin{aligned}
\Delta \ln M P R_{t}= & 0.007133 \mathrm{ECM}_{t}-0.022969 \Delta \ln \mathrm{MPR}_{t-1}+0.291075 \Delta \ln \mathrm{MPR}_{t-2} \\
& +0.000096 \Delta \mathrm{CRU}_{t-1}-0.001694 \Delta \mathrm{CRU}_{t-2}+0.000863 \Delta \ln \mathrm{COC}_{t-1} \\
& +0.000244 \Delta \ln \mathrm{COC}_{t-2}-0.000577 \Delta \ln _{\mathrm{GLD}} \\
& -0.000482 \Delta \ln \mathrm{GLD}_{t-2}+0.006248
\end{aligned}
$$

In the short run, the first lag of monetary policy rate is negative related to itself and the second lag of monetary policy rate is positively related to itself. The first lag of crude oil price is positively related to monetary policy rate and the second lag of crude oil price is negatively related to monetary policy rate. The first and second lagged periods of cocoa price has positive influence on monetary policy rate in the short run, but the first and second lagged periods of gold 
price has negative influence on monetary policy rates in the short run.

\subsection{Granger Causality Test}

In investigating whether or not one time series is useful in forecasting another, the study employed the Granger causality test. This test was used to investigate the existence of Granger-causality among MPR, CRU, COC and GLD. Table 4 captures the results.

Clearly from Table 4, an F-Statistic $=4.45$ and p-value $=0.01$, indicates that monetary policy rate Granger cause only crude oil prices. Likewise an F-Statistic $=3.43$ and $\mathrm{p}$-value $=0.03$, indicates that cocoa price Granger cause monetary prices.

\subsection{Impulse Response Functions and Variance Decomposition}

An impulse response refers to the reaction of any dynamic system in response to some external change. This describes how the economic variables react over time to exogenous impulses called shocks. Variance decomposition further evaluates the importance of different structure impacts through the analysis of each structure of endogenous variable's contribution. In other words, variance decomposition indicates the amount of information each variable contributes to the other variables in a vector autoregressive (VAR) models (Li \& Liu, 2012).

\section{Impulse response functions}

The results of the impulse response analysis for a time horizon of 12 months to a "one standard deviation" shock on MPR, CRU, COC and GLD are shown in Figure 2.

A positive shock in monetary policy rate will have a positive and persistent effect on itself. Likewise, positive shock in monetary policy rate will have a positive

Table 4. Granger causality test.

\begin{tabular}{cccc}
\hline Null Hypothesis: & Obs & F-Statistic & Prob. \\
\hline CRU does not Granger Cause MPR & 154 & 2.39723 & 0.0945 \\
MPR does not Granger Cause CRU & & 4.45097 & 0.0133 \\
COC does not Granger Cause MPR & 154 & 3.43350 & 0.0348 \\
MPR does not Granger Cause COC & & 1.77403 & 0.1732 \\
GLD does not Granger Cause MPR & 154 & 1.41317 & 0.2466 \\
MPR does not Granger Cause GLD & & 1.72521 & 0.1817 \\
COC does not Granger Cause CRU & 154 & 0.51454 & 0.5988 \\
CRU does not Granger Cause COC & & 0.60912 & 0.5452 \\
GLD does not Granger Cause CRU & 154 & 0.59754 & 0.5515 \\
CRU does not Granger Cause GLD & & 0.78080 & 0.4599 \\
GLD does not Granger Cause COC & 154 & 0.38468 & 0.6813 \\
COC does not Granger Cause GLD & & 2.38027 & 0.0960 \\
\hline
\end{tabular}


Response to Cholesky One S.D. Innovations
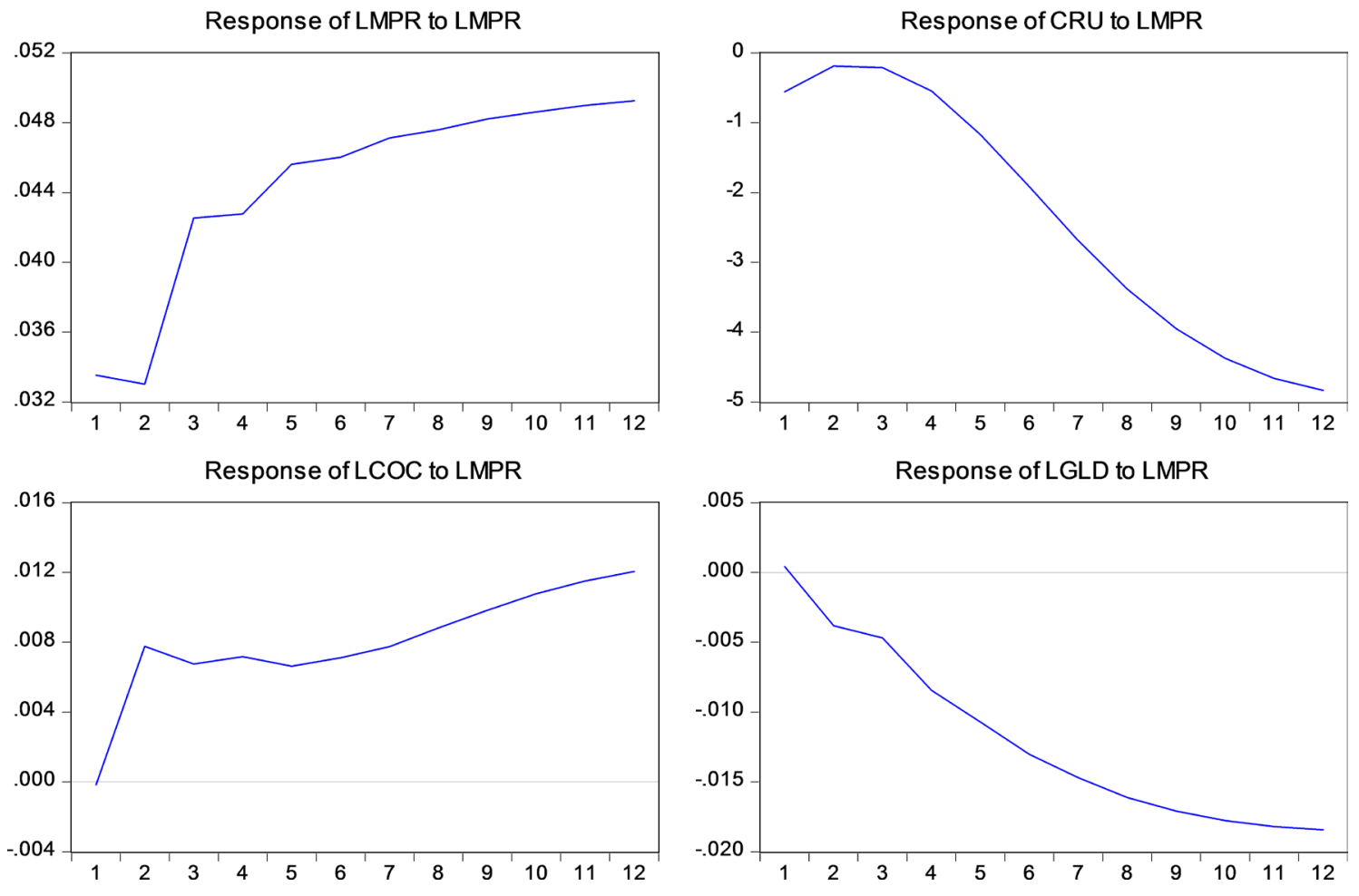

Figure 2. Impulse response functions.

and persistent effect on coccoa prices. The response generated from a positive shock on monetary policy rate has a persistent and decreasing effect on both crude oil and gold prices.

\subsection{Variance Decomposition}

Table 5 displays the variance decomposition of MPR, not considering the variance contribution of MPR to itself; crude, cocoa and gold prices contributed about $1 \%, 3 \%$ and $0.6 \%$ to MPR respectively.

It is evident from Table 6 that, not considering the contribution of crude price to itself, the contribution of MPR to crude oil price increased gradually all the period and reached a maximum of $31 \%$ at the twelfth period, at the same period, the contribution of cocoa and gold to crude price were $1 \%$ and $10 \%$ respectively.

It can be observed from Table 7 that, the variance contribution of cocoa price to itself is about $90 \%$, the variance contribution rate of MPR to cocoa was almost constant throughout the period and reached a maximum of about $3 \%$ at the twelve period while the contribution of crude price and gold to cocoa price were about $5 \%$ and $2 \%$ respectively.

It can be seen from Table 8 that, the variance contribution of gold price to itself is about $91 \%$, the variance contribution rate of MPR to gold increased steadily throughout the period and reached a maximum of about $6 \%$ at the twelfth period while the contribution of crude price and cocoa to gold price were about $2 \%$ and $1 \%$ respectively. 
Table 5. Variance Decomposition of MPR.

\begin{tabular}{cccccc}
\hline Period & S.E. & MPR & CRU & COC & GLD \\
\hline 1 & 0.571725 & 100.0000 & 0.000000 & 0.000000 & 0.000000 \\
2 & 0.806827 & 99.12225 & 0.043003 & 0.720361 & 0.114388 \\
3 & 1.107392 & 98.49629 & 0.052023 & 1.193458 & 0.258227 \\
4 & 1.344962 & 97.92072 & 0.083035 & 1.673326 & 0.322922 \\
5 & 1.578790 & 97.51963 & 0.128447 & 1.993337 & 0.358589 \\
6 & 1.786211 & 97.14887 & 0.208383 & 2.249880 & 0.392872 \\
7 & 1.983634 & 96.83086 & 0.316522 & 2.424497 & 0.428117 \\
8 & 2.167493 & 96.51641 & 0.453538 & 2.563957 & 0.466093 \\
9 & 2.342990 & 96.21571 & 0.606445 & 2.673578 & 0.504268 \\
10 & 2.509698 & 95.92652 & 0.765081 & 2.767542 & 0.540857 \\
11 & 2.669259 & 95.65990 & 0.917869 & 2.848168 & 0.574064 \\
12 & 2.821762 & 95.41940 & 1.058110 & 2.919294 & 0.603196 \\
\hline
\end{tabular}

Table 6. Variance Decomposition of CRU.

\begin{tabular}{cccccc}
\hline Period & S.E. & MPR & CRU & COC & GLD \\
\hline 1 & 0.571725 & 1.459442 & 98.54056 & 0.000000 & 0.000000 \\
2 & 0.806827 & 0.934554 & 98.51166 & 0.553054 & 0.000732 \\
3 & 1.107392 & 0.779125 & 98.21123 & 1.005330 & 0.004313 \\
4 & 1.344962 & 1.045300 & 97.46710 & 1.424476 & 0.063122 \\
5 & 1.578790 & 1.941270 & 95.83777 & 1.805594 & 0.415363 \\
6 & 1.786211 & 3.939335 & 92.74226 & 2.045710 & 1.272690 \\
7 & 1.983634 & 7.294854 & 87.92825 & 2.096390 & 2.680509 \\
8 & 2.167493 & 11.85247 & 81.70122 & 1.996426 & 4.449884 \\
9 & 2.342990 & 17.02571 & 74.86974 & 1.829584 & 6.274967 \\
10 & 2.509698 & 22.20254 & 68.21356 & 1.665906 & 7.917994 \\
11 & 2.669259 & 26.97605 & 62.20504 & 1.537011 & 9.281898 \\
\hline 12 & 2.821762 & 31.18674 & 56.99575 & 1.445123 & 10.37238 \\
\hline
\end{tabular}

Table 7. Variance Decomposition of COC.

\begin{tabular}{cccccc}
\hline Period & S.E. & MPR & CRU & COC & GLD \\
\hline 1 & 0.571725 & 0.141954 & 2.455244 & 97.40280 & 0.000000 \\
2 & 0.806827 & 1.427710 & 2.413723 & 95.95473 & 0.203840 \\
3 & 1.107392 & 1.342973 & 1.971971 & 95.62395 & 1.061107 \\
4 & 1.344962 & 1.410244 & 1.795249 & 95.13043 & 1.664074 \\
5 & 1.578790 & 1.415993 & 1.851479 & 94.79513 & 1.937399 \\
6 & 1.786211 & 1.503113 & 2.121074 & 94.36047 & 2.015342 \\
\hline
\end{tabular}


Continued

\begin{tabular}{llllll}
\hline 7 & 1.983634 & 1.622042 & 2.581439 & 93.80723 & 1.989293 \\
8 & 2.167493 & 1.792796 & 3.166628 & 93.12703 & 1.913547 \\
9 & 2.342990 & 1.985095 & 3.799697 & 92.39374 & 1.821467 \\
10 & 2.509698 & 2.189323 & 4.414197 & 91.66665 & 1.729834 \\
11 & 2.669259 & 2.386894 & 4.969335 & 90.99718 & 1.646592 \\
12 & 2.821762 & 2.570209 & 5.446868 & 90.40839 & 1.574534 \\
\hline
\end{tabular}

Table 8. Variance Decomposition of GLD.

\begin{tabular}{cccccc}
\hline Period & S.E. & MPR & CRU & COC & GLD \\
\hline 1 & 0.571725 & $5.58 \mathrm{E}-06$ & 1.596358 & 0.408745 & 97.99489 \\
2 & 0.806827 & 0.541596 & 2.343087 & 3.649474 & 93.46584 \\
3 & 1.107392 & 0.733302 & 2.086245 & 3.335461 & 93.84499 \\
4 & 1.344962 & 1.389414 & 1.590777 & 2.671667 & 94.34814 \\
5 & 1.578790 & 1.970989 & 1.257505 & 2.205155 & 94.56635 \\
6 & 1.786211 & 2.634973 & 1.105702 & 1.865514 & 94.39381 \\
7 & 1.983634 & 3.250143 & 1.110002 & 1.603310 & 94.03655 \\
8 & 2.167493 & 3.852819 & 1.218028 & 1.395286 & 93.53387 \\
9 & 2.342990 & 4.401011 & 1.379762 & 1.228088 & 92.99114 \\
10 & 2.509698 & 4.900163 & 1.555202 & 1.092437 & 92.45220 \\
11 & 2.669259 & 5.339236 & 1.720167 & 0.981677 & 91.95892 \\
12 & 2.821762 & 5.722496 & 1.862899 & 0.890435 & 91.52417 \\
\hline
\end{tabular}

\subsection{Model Diagnostics}

The VEC serial correlation LM test which is distributed as chi-square has a value of 13.98687 ( $\mathrm{p}$-value $=0.5997$ ) and the VEC Residual Portmanteau Tests for Autocorrelations had a value of $14.71663(\mathrm{p}$-value $=0.9813)$. This shows that the diagnostic tests for serially uncorrelated errors, normality, and heteroscedasticity are satisfied at $5 \%$ level of significance. Recursive estimation of the errors also suggests that the regression coefficients are stable over the sampled period. This is because the Cumulative Sum (CUSUM) plot based on the recursive residuals given in Figure 3 does not show evidence of statistically significant breaks. The CUSUM plot shows the stability of the VEC model.

Findings of this study provide a comprehensive understanding of the dynamic relationship among the movement monetary policy rates and the major commodity prices in Ghana. In line with the earlier findings made by Anzuini et al. (2012) and Cabrales et al. (2014) the present study based on Johansen's co-integration test confirms the existence of a significant long run co-integrating relationship between monetary policy rates and the major commodity prices in Ghana. The causality test based on VECM framework indicates a significant unidirectional long term causality which runs from Ghanaian cocoa prices to monetary policy rate. 


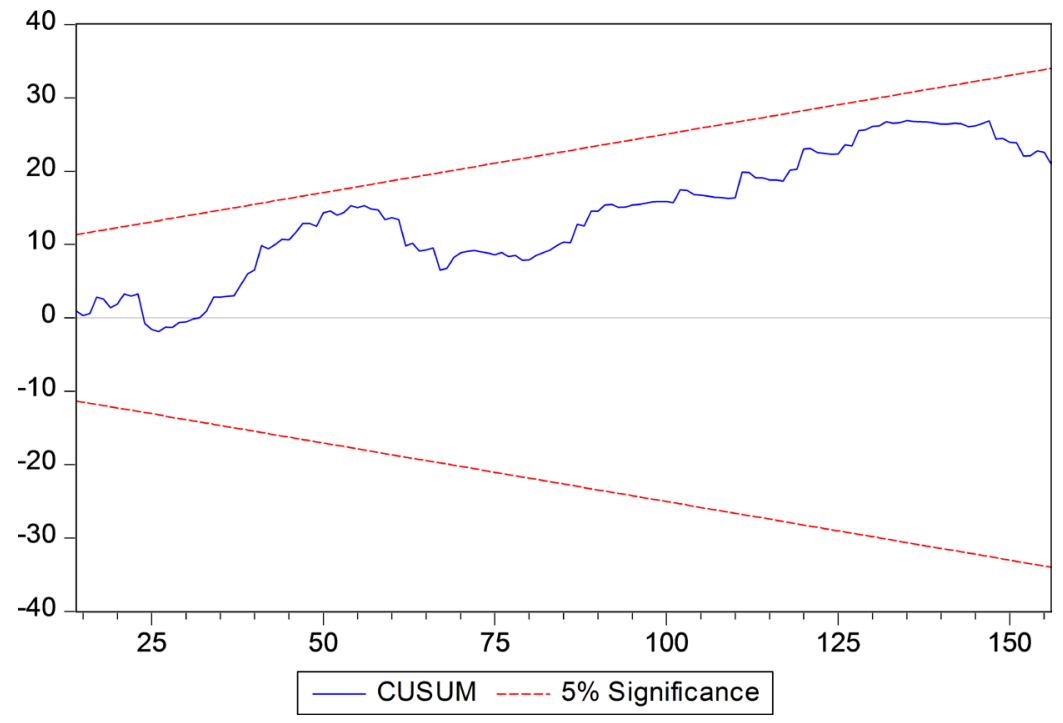

Figure 3. CUSUM test for stability.

In as much as the VEC model established a short run relationship between monetary policy rate and the major Ghanaian commodity prices, there was no significant effect or impact of monetary policy rates on the major Ghanaian commodity prices. This is may be due to lack of added value to the commodities such as the gold and cocoa.

\section{Conclusion}

The study employed the Vector Error Correction (VEC) model to assess the impact of monetary policy rate on commodity prices in Ghana. It is evident from the study that in the long term, there is an equilibrium relationship among MPR, crude oil, cocoa and gold prices. The study revealed that in the long run, monetary policy rates are negatively correlated with crude oil prices, when crude oil prices increase by $1 \%$, the monetary policy rates fall by $0.22 \%$; monetary policy rates are positively correlated with cocoa prices but to a little extent, when cocoa prices increase by $100 \%$, the monetary policy rates increase by $0.06 \%$; and monetary policy rates are positively correlated with gold prices but to a little extent, when gold prices increase by $10 \%$, the monetary policy rates increase by $0.08 \%$.

It was also evident from the study that in the short run, the first lag of monetary policy rate is negatively related to itself and the second lag of monetary policy rate is positively related to itself. The first lag of crude oil price is positively related with the monetary policy rate and the second lag of crude oil price is negatively related to monetary policy rate. The first and second lagged periods of cocoa price has positive influence on monetary policy rate in the short run, but the first and second lagged periods of gold price have negative influence on monetary policy rates in the short run.

It can be seen from the impulse response function and variance decomposition of the variables that the shock to the cocoa, gold and MPR is mainly caused by the change of themselves and MPR has a greater impact on crude oil prices 
and a relatively small impact on gold and cocoa prices.

In as much as the VEC model employed by the study established the long and the short term relationships or the dynamic relationships of the macroeconomic variables considered in the study, there were some limitations of the VEC model. One of the drawbacks of the VEC model was its inability to handle several variables. Several variables in VEC model imply several parameters to be estimated which may cause over-parameterization. Consequently, in this study, several commodities such as bauxite, diamond, and manganese were not considered.

Another drawback of the VEC model was conditional forecasting which means that a variable interest is predicted, while values for different variables within the VEC model are assumed over the prediction interval. As a result, prediction or forecasting was not conducted in this study. For future studies to address these limitations, the study suggests the utilization of the Bayesian Multivariate Time Series methods.

\section{Conflicts of Interest}

The authors declare no conflicts of interest regarding the publication of this paper.

\section{References}

Anzuini, A., \& Fornari, F. (2012). Macroeconomic Determinants of Carry Trade Activity. Review of International Economics, 20, 468-488.

https://doi.org/10.1111/j.1467-9396.2012.01034.x

Anzuini, A., Lombardi, M. J., \& Pagano, P. (2012). The Impact of Monetary Policy Shocks on Commodity Prices. Bank of Italy Temi di Discussione Working Paper No. 851. https://doi.org/10.2139/ssrn.2030797 https://papers.ssrn.com/sol3/papers.cfm?abstract id=2030797

Bernanke, B. S., \& Blinder, A. S. (1992). The Federal Funds Rate and the Channels of Monetary Transmission. The American Economic Review, 82, 901-921. https://ideas.repec.org/a/aea/aecrev/v82y1992i4p901-21.html

Blanchard, O. J., \& Gali, J. (2007). The Macroeconomic Effects of Oil Shocks: Why Are the 2000s So Different from the 1970s? Cambridge, MA: National Bureau of Economic Research. https://doi.org/10.3386/w13368

Bleaney, M., \& Greenaway, D. (1993). Long-Run Trends in the Relative Price of Primary Commodities and in the Terms of Trade of Developing Countries. Oxford Economic Papers, 45, 349-363. https://doi.org/10.1093/oxfordjournals.oep.a042096

Cabrales, C. A., Granados Castro, J. C., \& Ojeda Joya, J. (2014). The Effect of Monetary Policy on Commodity Prices: Disentangling the Evidence for Individual Prices. Economics Research International, 2014, Article ID: 649734.

https://doi.org/10.1155/2014/649734

Christiano, L. J., Eichenbaum, M., \& Evans, C. L. (1998). Modeling Money. Cambridge, MA: National Bureau of Economic Research. https://doi.org/10.3386/w6371

Ford, J. L., Agung, J., Ahmed, S., \& Santoso, B. (2003). Bank Behaviour and the Channel of Monetary Policy in Japan, 1965-1999. The Japanese Economic Review, 54, 275-299. https://ideas.repec.org/a/bla/jecrev/v54y2003i3p275-299.html

https://doi.org/10.1111/1468-5876.00259 
Frankel, J. A. (2008). The Effect of Monetary Policy on Real Commodity Prices. In Asset Prices and Monetary Policy (pp. 291-333). National Bureau of Economic Research, Inc. https://ideas.repec.org/h/nbr/nberch/5374.html https://doi.org/10.3386/w12713

Frankel, J. A. (1986). Expectations and Commodity Price Dynamics: The Overshooting Model. American Journal of Agriculture Economics, 68, 344-348. https://ideas.repec.org/a/oup/ajagec/v68y1986i2p344-348..html https://doi.org/10.2307/1241436

Frankel, J. A. (2005). Why Are Oil and Metal Prices High? Don't Forget Low Interest Rates. Financial Times, 15. https://sites.hks.harvard.edu/

Frankel, J. A., \& Rose, A. K. (2010). Determinants of Agricultural and Mineral Commodity Prices. https://ideas.repec.org/p/ecl/harjfk/rwp10-038.html

Henderson, B. J., Pearson, N. D., \& Wang, L. (2014). New Evidence on the Financialization of Commodity Markets. The Review of Financial Studies, 28, 1285-1311. https://doi.org/10.1093/rfs/hhu091

Li, C.-S., \& Liu, Z.-J. (2012). Study on the Relationship among Chinese Unemployment Rate, Economic Growth and Inflation. Advances in Applied Economics Finance, 1, 1-6. https://www.academia.edu/34295802/Study on the relationship among Chinese une mployment rate economic growth and inflation

Lütkepohl, H., Krätzig, M., \& Phillips, P. C. (2004). Applied Time Series Econometrics. Cambridge: Cambridge University Press. https://doi.org/10.1017/CBO9780511606885

Sims, C. A. (1980). Macroeconomics and Reality. Journal of the Econometric Society, 48, 1-48. https://doi.org/10.2307/1912017

Thomasz, E., Massot, J., \& Rondinone, G. (2016). Is the Interest Rate More Important than Inventories? The Case of Agricultural Commodities in the Context of the Financialization Process. Lecturas de Economia, 85, 127-153. https://doi.org/10.17533/udea.le.n85a04

Tang, K., \& Xiong, W. (2012). Index Investment and the Financialization of Commodities. Financial Analysts Journal, 68, 54-74. https://doi.org/10.2469/faj.v68.n6.5 https://www.tandfonline.com/doi/abs/10.2469/faj.v68.n6.5 